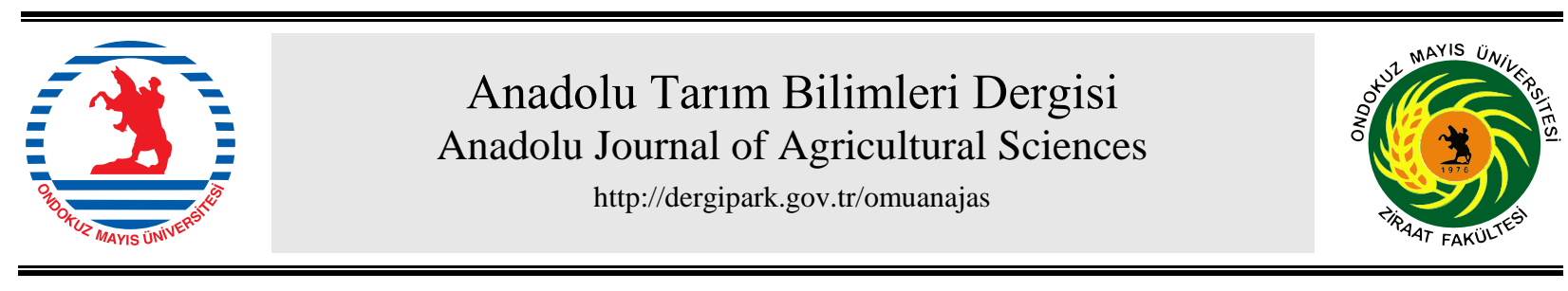

Araştırma/Research

Anadolu Tarım Bilim. Derg./Anadolu J Agr Sci, 32 (2017)

ISSN: 1308-8750 (Print) 1308-8769 (Online)

doi: 10.7161/omuanajas.321121

\title{
Aspir küspesinin tavuklarda performans, yumurta kalite özellikleri, yumurta sarısı yağ asitleri ve kolesterol düzeyine etkisi
}

\author{
Süleyman Çalışlar*, Hüseyin Kuştimur \\ KSÜ Ziraat Fakültesi Zootekni Bölümü \\ *Sorumlu yazar/corresponding author: scalislar@ksu.edu.tr \\ Geliş/Received 08/09/2016 Kabul/Accepted 01/01/2017
}

\begin{abstract}
ÖZET
$\mathrm{Bu}$ araştırmada, aspir (Carthamus tinctorius L.) küspesinin (AK) tavukların performans parametreleri, yumurta kalite özellikleri, yumurta sarısı yă̆ asitleri ve kolesterol oranına etkileri incelenmiştir. Tesadüf parselleri deneme deseninde yürütülen araştırmada, farklı oranlarda $\mathrm{AK}$ içeren altı muamele grubunun $(\% 0,3,6,9,12$ ve 15$)$ her birinde 12'şer tekerrür olmak üzere, 43 haftalık yaşta toplam 72 adet kahverengi yumurtacı Lohmann 1rkı tavuk kullanılmıştır. Yem ve su ad libitum olarak verilmiş, günlük toplam aydınlatma süresi 16.5 saat olarak uygulanmıştır. Dokuz hafta (63 gün) süren araştırmada, AK'nın farklı dozları canlı ağırlık, yem tüketimi, yem dönüşüm oranı, yumurta verimi, yumurta ağırlığı, şekil indeksi, ak indeksi, sarı indeksi, kabuk ağırlığı, kabuk kalınlığı, kabuk kırılma direnci, Haugh birimi, sarı ağırlığı, sarı yağ oranı ve sarı renk değerlerini etkilememiştir $(\mathrm{P}>0.05)$. Ancak, yumurta sarısı kolesterolü, yumurta sarısı toplam doymuş yağ asitleri ve toplam doymamış yă̆ asitleri miktarı üzerine AK'nın farklı dozlarının etkisi önemli olmuştur $(\mathrm{P}<0.05)$.

$\mathrm{Bu}$ araştırma sonuçlarına göre, performans, ölüm oranı ve yumurta kalitesine herhangi bir olumsuz etkisi olmaksızın, AK'nin yumurtacı tavukların rasyonlarında \% 15 oranına kadar kullanılabileceği görülmüştür.
\end{abstract}

The effects of safflower meal on the performance, egg quality traits, yolk fatty acids and cholesterol levels in laying hens

\section{ABSTRACT}

In this study, the effects of safflower (Carthamus tinctorius L.) meal (SM) on performance parameters, egg internal-external quality characteristics and egg yolk fatty acid profiles, yolk cholesterol ratio in laying hens were examined. The research design was a completely randomized design. The treatments were represented by six diets with increasing levels of inclusion $(0,3,6,9,12$ ve 15\%) of SM and each group had twelve replications. Each replication had one laying hen and 43 weeks old 72 laying hen were used in study. The water and feed were given ad libitum. The daily lighting time was 16.5 hours. In the present study, which lasted for nine weeks (63 days), the different doses of SM did not affect the liveweight, feed consumption, feed conversion ratio, egg yield, egg weight, shape index, albumen index, yolk index, shell weight, shell thickness, shell strength, Haugh unit, yolk weight, yolk fat ratio and yolk colour $(\mathrm{P}>0,05)$. But, the effects of different doses of SM on cholesterol, total saturated fatty acid and total unsaturated fatty acid contents of egg yolk were found significant $(\mathrm{P}<0.05)$.

According to the results of this study, safflower meal can be used in laying hen diets up to $15 \%$ without any adverse effects on performance, mortality and egg quality traits.

Anahtar Sözcükler:

Aspir küspesi

Tavuk

Yumurta

Performans

Kolesterol

Yağ asitleri
Keywords:

Safflower meal

Laying hen

Egg

Performance

Cholesterol

Yolk fatty acids

\section{Giriş}

Aspir tohumu (Chartamus tinctorius L.) yağlı tohum bitkilerinden birisi olan aspir, tek yıllık ve otsu yapıda olup papatyagiller (Compositae) familyasının bir üyesidir. Aspir bitkisi, eski zamanlarda (M.Ö 4500) Mısır, Fas, Çin ve Hindistan'da kumaşları sarı ve kırmızıya boyamak için kullanılmıştır (Dajue ve Mündel, 1996). Günümüzde ise aspir bitkisi, yağından yararlanmak ve farklı endüstriyel amaçlar için yetiştirilmektedir. Aspir tohumu Türkiye'de stratejik önemi her geçen gün artan bir bitki haline gelmiştir.

Aspir tohumu, \%33-60 kabuk ve \% 40-67 çekirdek kısmından meydana gelmiş (Mündel ve ark., 2004; 
Baümler ve ark., 2006; Oyen ve Umali., 2007) olup \% 13-46 arasında yağ ve \% 15-20 arasında protein içermektedir (Rahamatalla ve ark., 2001). Aspir tohumu, pet hayvanları başta olmak üzere kanatlı hayvanların beslenmesinde kullanılan pahalı bir yem hammaddesidir (Mündel ve ark., 2004). Hayvan yemi olarak kullanılan aspir küspesinin (Weiss, 2000; GRDC, 2010) yağ oranı \% 2-15 arasında değişir (Nagaraj, 1993). Aspir küspesi, \% 91 kuru madde (KM), \% 20 ham protein (HP), \% 6.6 ham yağ (HY), \% 32.2 ham selüloz (HS), \%3.7 ham kül (HK), \% 0.23 kalsiyum (Ca), \% 0.61 toplam fosfor (TP), $1160 \mathrm{kcal}$ metabolik enerji (ME/kg), \% 0.40 metiyonin ve \% 0.70 lisin içeriğine sahiptir (Batal ve ark., 2016). Kabuk miktarı ve yağ ekstraksiyonunun derecesine bağlı olarak AK'nın besin içeriği değişiklik gösterir. Kabuğu alınmamış AK \% 20-25 HP (Göhl, 1982; Dajue ve Mündel, 1996) ve \%30-40 HS (GRDC, 2010) içermektedir. Kabuğu alınmış AK'nın HP miktarı \% 40'a yükselirken (Alvarez-Gonzalez ve ark., 2007) HS oranı ise \% 10'a düşmektedir (GRDC, 2010). Kabuğunun tam olarak alınmasıyla protein ve aminoasitlerinin sindirilebilirliği artan AK, soya küspesiyle (SK) kıyaslanabilir hale gelmektedir (Farran ve ark., 2010). Diğer yağlı tohum küspelerine göre vitamin profili daha zayıf olan AK'nın, iyi bir biyotin, riboflavin ve niyasin kaynağı olduğu ve SK'ya göre 3.5 kat daha fazla demir içerdiği bildirilmiştir (Darroch, 1990). AK iyi bir fosfor, çinko ve demir kaynağıdır (Gowda ve ark., 2004). Bununla birlikte aspir tohumunda bulunan ve kısmen AK'ya geçen fenolik glikozidler acı tada, ishale neden olmakta ve besin maddelerinden yararlanmayı azaltabilmektedir (Palter ve ark., 1972; Sakamura ve ark., 1978).

Kanatlıların beslenmesinde kullanımı önem arz eden enerji kaynaklarından birisi de yağlı tohumlardır (Dajue ve Mündel, 1996). Enerji, lisin ve metiyonin düzeyleri göz önünde bulundurulmak kaydiyla kanatlı hayvan rasyonlarında kullanım imkânı olan yağlı tohumlu bitkilerden birisi de aspirdir. Ancak aspir tohumunun yüksek kabuk (selüloz) içermesi onun kanatlı rasyonlarında kullanımını sinırlandırmaktadır (Hertrampf ve Piedad-Pascual, 2000; Abughazaleh ve ark., 2005). Aspir küspesinin metabolik enerji değeri, civcivlere göre piliçlerde daha yüksektir (5.4-8.9 MJ kg ${ }^{-1}$ ) (Petersen ve ark., 1976). Yumurtacı tavuk rasyonlarının \% 10-15, genç civciv rasyonlarının ise \% 5-8 oranlarında $\mathrm{AK}$ içermesi ön görülmüştür (Heuzé ve ark., 2015).

Kabuğu alınmış AK içeren (kabuğu alınmış) ve lisin ilave edilmemiş diyetlerle yapılan beslemede, broyler piliçlerin performansı neredeyse yarıya düşmüştür. Diyetlere lisin ilave edilmesine bağlı olarak broyler piliçler performanslarını muhafaza edebilmişlerdir (Mohan ve ark., 1984). Tek mideli hayvanların beslenmesinde, SK'ya göre AK'nın lisin, metiyonin ve izolözin içerikleri ve yararlanabilirliklerinin daha düşük olduğu görülmüştür (Darroch, 1990). Farklı oranlarda $(\% 0,2.5,5.0$ ve 10$)$ AK içeren rasyonların tavukların yem tüketimi ve yumurta verimini etkilemediği $(\mathrm{P}>0.05)$, yemden yararlanma oranını olumsuz yönde etkilediği, \% 5 düzeyine kadar AK kullanılmasının ise tavukların performansı üzerinde olumsuz bir etkiye neden olmadığı bildirilmiştir (Ehsani ve ark., 2013).

Bu çalışmada, AK'nın, rasyonlarda kullanım imkânı, proteince zengin yem hammaddelerine (SK vb.) alternatif olabilme potansiyeli, tavukların genel performansına, yumurta kalite özelliklerine, yumurta sarısı yağ asitleri ve kolesterol içeriğine etkileri araştırılmıştır. sodyum ile rekabet edecek K miktarını arttırmakta ve bozulmuş olan hücre içi $\mathrm{Na} / \mathrm{K}$ dengesini yeniden ayarlayarak metabolik düzenlemeyi yeniden sağlamaktadır (Kaya ve Tuna, 2005). Silisyum yüksek organizmalar için temel element olduğu görüşü öne sürülmektedir. Tuzlu topraklara uygulanan silisyum, tuzları sodyum silikat şeklinde bağlayarak bitki tarafından alınan Na miktarını ve bitkilerde oluşacak tuz hasarını yani tuz stresini azalmaktadır. Bu etki fotosentetik aktivitenin $\mathrm{K} / \mathrm{Na}$ oranının, enzim aktivitesinin ve ksilemde çözünebilir madde konsantrasyonunun artmasıyla gerçekleşir.

Tarımda hızla artan tuzluluk probleminin çözümüne küçükte olsa bir katkı sağlamak amacıyla düzenlenen bu çalışmada, tuz stresinden etkilenme potansiyeli yüksek hassas bir bitki olan biberin tuzluluğa direncini arttırabileceğini düşündüğümüz hem organik hem de inorganik bazı bileşikleri test ederek biber bitkisinin verdiği karşı yanıt araştırılmıştır.

\section{Materyal ve Yöntem}

\subsection{Materyal}

Çalışma süresince kümes içi sıcaklığ $120-25{ }^{\circ} \mathrm{C}$, nemi ise \% 40 ile \% 70 arasında değişim göstermiştir. Havalandırma için aspiratör $\left(15 \mathrm{kw} \mathrm{h}^{-1}\right)$ kullanılmışı̧ır. Denemede toplam 72 adet 43 haftalık yaştaki kahverengi yumurta tavuğu (Lohman 1rk1) kullanılmıştır. Tüm araştırma süresince Lohman ırkına ait yetiştirme önerilerine (Hastavuk Teknik el Kitabı) göre hareket edilmiştir. Tavuklar, galvanizli malzemeden yapılmış bireysel bölmeli kafeslerde barındırılmıştır. Kümesin aydınlatması flüoresan lambalar ile sağlanmış, deneme süresince gün ışığı ile birlikte tavuklara günlük toplam 16.5 saat aydınlatma uygulanmış, yem ve su ad-libitum verilmiştir. Toz formundaki yemler bireysel yemliklerde sunulmuş, su ad-libitum verilmiştir. Toz formundaki yemler bireysel yemliklerde sunulmuş, su ihtiyacı nipel suluklar ile sağlanmıştır.

Tesadüf parselleri desenine göre düzenlenen çalışma, \% 0 AK (kontrol; 1. grup), \% 3 AK (2.grup), \% 6 AK (3. grup), $\% 9$ AK (4.grup), \% 12 AK (5. grup) ve $\% 15$ AK (6. grup) olmak üzere toplam 6 muamele grubundan oluşmuş ve her grupta 12 'şer tekerrür yer almıştır. Kontrol grubu rasyonu küspe olarak sadece SK içermiştir. İkinci rasyona SK'nın sağladığı proteinin $\%$ 6'sın', 3. rasyona \% 12'sini, 4. rasyona \% 19'unu, 5. 
rasyona \% 27'sini ve 6. rasyona ise \% 36'sını karşılayacak kadar AK ikame edilerek 6 rasyon hazırlanmıştır.

Altmış üç günde tamamlanan çalışmada, 43 haftalık yaşta toplam 72 adet Lohman 1rkı kahverengi yumurta tavuğu kullanılmıştır. Besin maddeleri içerikleri analiz edilen ve NRC değerleri esas alınarak izonitrojenik ve izokalorik (\% 17.5 ham protein ve $2750 \mathrm{kcal} \mathrm{kg}^{-1} \mathrm{ME}$ ) olarak hazırlanan rasyonlar kullanılmıştır.

Çizelge 1. Araştırmada kullanılan yem hammaddeleri ve bunların analiz edilmiş besin madde değerleri, $\left(\mathrm{g} \mathrm{kg}^{-1}\right)$

\begin{tabular}{lcccccc}
\hline Hammadde & $\begin{array}{c}\text { Ham } \\
\text { protein }\end{array}$ & $\begin{array}{c}\text { Ham } \\
\text { yağ }\end{array}$ & Ham selüloz & Nişasta & $\begin{array}{c}\text { Toplam } \\
\text { şeker }\end{array}$ & $\begin{array}{c}\text { ME } \\
(\mathrm{kcal} / \mathrm{kg})\end{array}$ \\
\cline { 2 - 7 } Mısır & 8.32 & 3.62 & 1.72 & 55.12 & 1.60 & 3046.52 \\
SK & 49.36 & 2.43 & 2.85 & 0.12 & 8.50 & 2480.61 \\
AK & 23.52 & 1.34 & 41.01 & 0.12 & 2.57 & 1168.90 \\
Ham soya yağı & - & 99.88 & - & - & - & 8990.00 \\
\hline
\end{tabular}

SK: Soya küspesi, AK: Aspir küspesi, ME: Metabolik enerji (kcal kg ${ }^{-1}$ )

\subsection{Metot}

Yumurta tavuklarının canlı ağılık değişimleri, yem tüketimi, yemden yararlanma oran1, yumurta verimi, yumurta ağırlı̆̆ı, ölüm oranı, yumurta kalite özellikleri (sar1 ağırlığı, sarı rengi, Haugh birimi, ak indeksi, sarı indeksi, şekil indeksi, kabuk kalınlığı, kabuk ağırlığı, yumurta sarısı renk yelpaze değerleri), yumurta sarısı HY, kolesterol ve toplam yağ asitleri miktarı bu denemede incelenen temel parametreler olmuştur. Çalışmada kullanılan AK'ya ait gerekli kimyasal analizler yapılmıştır.

Tavuklar, çalışmanın $0,21,42$ ve 63. günlerinde hassas terazide bireysel olarak 4 kez tartılmışlardır. Haftalık bazda kaydedilen yem tüketim miktarları, gün sayısına bölünmek suretiyle günlük tüketilen yem miktarı cinsinden belirtilmiștir. Yem tüketim miktarlarının yumurta ağırlığına oranlanmasıyla yemden yararlanma oranı hesaplanmıştır. Yumurta verimleri tavuk-gün esasına göre (\%) tespit edilmiștir.

İç-dış kalite özelliklerini belirlemek için çalışmanın $2,4,6$ ve 8 . haftalarında toplam $4 \mathrm{kez}$ yumurta toplanmış ve analizleri yapılmıştır. Kabuk ağırlığı (zarı elle ayrılmış) hassas terazi, kabuk kalınlığı hassas mikrometre $(0.01 \mathrm{~mm})$ ile saptanmıştır. Kabuk kırılma direnci $0-5 \mathrm{~kg}$ aralığında kuvvet uygulayan kabuk direnci ölçme cihazı ile $\mathrm{kg} \mathrm{cm}^{-2}$ olarak tespit edilmiştir. Sarı ve ak yüksekliği üçayaklı mikrometre, sarı çapı, ak uzunluğu ve ak genişliği ise hassas dijital göstergeli kumpas $(0.01 \mathrm{~mm})$ ile ölçülmüştür. Bu ölçüm değerleri kullanılarak hesaplama yoluyla sarı indeksi ve ak indeksi değerleri belirlenmiştir. Yumurta ak yüksekliği ve yumurta ağırlığına ait ölçülen değerler formülde (100 $\mathrm{x} \log (\mathrm{H}+7,57-1,7)$ x W0,37) yerine konularak Haugh birimi tespit edilmiştir (Şenköylü, 2001). Yumurta sarı renginin belirlenmesinde renk yelpazesi (DSM) kullanılmıştır. Araştırmanın 21. ve 63. günlerinde alınan yumurta sarısı örneklerinde HY, kolesterol, toplam doymuş ve doymamış yağ asiti miktarları belirlenmiştir.

Araştırmada kullanılan yem hammaddelerinin besin maddeleri içerikleri Çizelge 1'de verilmiştir. Carpenter ve Clegg (1956) tarafindan belirtilen formül [38×(2.25 x
$\left.\mathrm{HY}, \mathrm{g} \mathrm{kg}^{-1}\right)+\left(1 \times \mathrm{HP}, \mathrm{g} \mathrm{kg}^{-1}\right)+\left(1.1 \times\right.$ Nişasta, $\left.\mathrm{g} \mathrm{kg}^{-1}\right)+$ $\left(1,05 \mathrm{x}\right.$ Şeker, $\left.\mathrm{g} \mathrm{kg}^{-1}\right)+53$ ] kullanılmak suretiyle araştırmaya ait rasyonların ME içerikleri $\left(\mathrm{Kcal} \mathrm{kg}{ }^{-1}\right)$ belirlenmiştir. Rasyonların kalsiyum, toplam fosfor, lisin ve metiyonin içerikleri için NRC (1994) tarafından belirtilen değerler kullanılmıştır.

Çalışmada kullanılan yem hammaddelerinin toplam şeker içerikleri, Dubois ve ark. (1956), nişasta içerikleri Karabulut ve Canbolat (2005), HP, HY ve HS analizleri ise AOAC, (2005) tarafından tanımlanan yöntemlere göre yapılmıştır. Çalışmaya ait yumurta sarılarının HY oranları (AOAC, 2005)'a göre belirlenmiştir. Yumurta sarısı kolesterol içerikleri ise Boehringer Mannheim Gmbh Biochemica (1989) tarafindan belirtilen yönteme göre $520 \mathrm{~nm}$ dalga boyunda spektrofotometrede (Spectra Max plus 384) belirlenmiştir. Yumurta sarılarından ekstrakte edilen ve esterleştirilen örneklerin yağ asitleri analizleri ise Folch ve ark. (1957)'e göre gaz kromotografi cihazında (Shimadzu, Model 2025) yapılmıştır.

Deneysel birim olarak bireysel hayvan verilerinin kullanıldığı araştırmada veriler, tek yönlü varyans analizine (one way anova) tabi tutulmuş ve ortalamalar arasındaki farklılıklar Duncan Çoklu Karşılaştırma Testi'ne göre belirlenmiştir. Tüm bu işlemler istatistik paket programı (SAS, 2005) kullanılarak yapılmıştır.

\section{Bulgular ve Tartışma}

\subsection{Yem hammaddeleri kompozisyonu}

$\mathrm{Bu}$ çalışmada kullanılan mısır, SK, AK ve soya ham yağının nem, HP, HY, HS, şeker ve nişasta değerlerine ait laboratuvar analiz sonuçları Çizelge 1'de, rasyonların yapısındaki hammaddeler ile bunların analiz edilen ve hesaplanan besin madde değerleri ise Çizelge 2'de verilmiştir. Çalışmada kullanılan AK'nın \% 67.21 oranında toplam doymamıș yağ ve \% 32.79 oranında toplam doymuş yağ içerdiği tespit edilmiştir. Yem hammaddelerinin analiz edilmiş besin madde değerleri kullanılarak hazırlandığı için, çalışmaya ait tüm rasyonların protein, enerji, metiyonin ve lisin 
düzeylerinin birbirlerine eşit olması sağlanmıştır

Çizelge 2).

Çizelge 2. Rasyonların hammadde içerikleri ve besin madde değerleri $(\mathrm{g} / \mathrm{kg})$

\begin{tabular}{|c|c|c|c|c|c|c|}
\hline \multirow{3}{*}{ Hammadde } & \multicolumn{6}{|c|}{ Gruplar } \\
\hline & 1 & 2 & 3 & 4 & 5 & 6 \\
\hline & $0-\mathrm{AK}$ & $3-\mathrm{AK}$ & $6-\mathrm{AK}$ & 9-AK & $12-\mathrm{AK}$ & $15-\mathrm{AK}$ \\
\hline Misir & 620.85 & 592.14 & 563.46 & 535.66 & 506.03 & 477.32 \\
\hline SK & 244.89 & 235.61 & 226.34 & 216.90 & 207.78 & 198.51 \\
\hline Mermer tozu & 80.88 & 81.05 & 81.23 & 81.40 & 81.57 & 81.74 \\
\hline $\mathrm{AK}$ & 0.00 & 30.00 & 60.00 & 90.00 & 120.00 & 150.00 \\
\hline Soya ham yağ1 & 26.38 & 34.82 & 43.25 & 51.42 & 60.13 & 68.57 \\
\hline DCP & 19.18 & 18.65 & 18.12 & 17.58 & 17.05 & 16.52 \\
\hline Metiyonin & 1.26 & 1.20 & 1.13 & 1.07 & 1.00 & 0.93 \\
\hline Lisin & 1.56 & 1.53 & 1.47 & 1.47 & 1.44 & 1.41 \\
\hline Tuz & 2.50 & 2.50 & 2.50 & 2.00 & 2.50 & 2.50 \\
\hline Vitamin + Mineral & 2.50 & 2.50 & 2.50 & 2.50 & 2.50 & 2.50 \\
\hline Toplam, kg & 1000 & 1000 & 1000 & 1000 & 1000 & 1000 \\
\hline \multicolumn{7}{|c|}{ Analiz edilmiş besin madde değerleri } \\
\hline Kuru madde, $\%$ & 89.83 & 89.99 & 90.16 & 90.31 & 90.48 & 90.64 \\
\hline Ham protein, $\%$ & 17.50 & 17.50 & 17.50 & 17.50 & 17.50 & 17.50 \\
\hline ME, Kcal / kg & 2750 & 2750 & 2750 & 2750 & 2750 & 2750 \\
\hline Ham yağ, \% & 5.34 & 6.04 & 6.74 & 7.42 & 8.14 & 8.84 \\
\hline Ham selüloz, \% & 1.76 & 2.92 & 4.07 & 5.23 & 6.38 & 7.53 \\
\hline \multicolumn{7}{|c|}{ Hesaplanmış besin madde değerleri } \\
\hline Ham kül, \% & 12.86 & 12.84 & 12.81 & 12.74 & 12.76 & 12.74 \\
\hline Toplam fosfor, $\%$ & 0.65 & 0.65 & 0.65 & 0.65 & 0.65 & 0.65 \\
\hline Lisin, $\%$ & 1.00 & 1.00 & 1.00 & 1.00 & 1.00 & 1.00 \\
\hline Metiyonin, \% & 0.40 & 0.40 & 0.40 & 0.40 & 0.40 & 0.40 \\
\hline
\end{tabular}

DCP: Dikalsiyum fosfat; SK: Soya küspesi, AK: Aspir küspesi; Vitamin+Mineral premiksi İçeriği (2.5 Kg):Vitamin A 12000000 IU, Vitamin D3 2000000 IU, Vitamin E 35000 mg, Vitamin K3 5000 IU, Vitamin B1 3000mg, Vitamin B2 6000mg, Vitamin B6 5000mg, Vitamin B 12 15mg, Vitamin C 50000mg, D-Biyotin 45mg, Niasin 20000mg, Kalsiyum D pantotenat $6000 \mathrm{mg}$, Folik asit $750 \mathrm{mg}$, Kolin klorid $125000 \mathrm{mg}$, Mangan $80000 \mathrm{mg}$, Demir $60000 \mathrm{mg}$, Çinko 60000mg, Bakır 5000mg, İyot 1000mg, Kobalt 200mg, Selenyum 150mg, Kantaksantin 20.000mg (karofil kirmızıs1), ß-apo-8'carotenoic acid ethyl ester $5.000 \mathrm{mg}$ (karofil sarıs1)

\subsection{Performans özellikleri}

Farklı oranlarda AK içeren rasyonlarla beslemenin tavukların canlı ağırlık değişimi, yem tüketimi, yumurta üretimi ve yemden yararlanma oranı üzerine etkisi Çizelge 3 ve Çizelge 4'de yer almıştır.

$\mathrm{Bu}$ çalışmada kullanılan AK miktarları, tavukların canlı ağırlık değiş̧imlerini etkilememiştir (P>0.05;Çizelge 2; Çizelge 3). Benzer şekilde, soya proteininin $\% 20, \% 40, \% 60$ ve $\% 80$ 'i yerine AK kullanılmasının (Barbour ve ark., 2016) ve AK içeren diyetlerle beslemenin (Ehsani ve ark., 2013) yumurta tavuklarının canlı ağırlık değişimine etkileri önemsiz olmuştur. Yem tüketim düzeyleri bakımından muamele grupları arasındaki farklılıklar önemsiz bulunmuştur $(\mathrm{P}>0.05)$. $\mathrm{Bu}$ sonuç, soya küspesi yerine $\mathrm{AK}$ içeren rasyonlarla beslemenin yumurta tavuklarının yem tüketimlerine etkisinin olmadığını bildiren çalışmalarla (Ehsani ve ark., 2013; Barbour ve ark., 2016) ile benzerlik gösterirken, değişik oranlarda $\mathrm{AK}$ içeren diyetlerin broyler piliçlerin yem tüketimlerini önemli derecede azalttığının bildirildiği çalışma sonuçları (Rehman ve Malik, 1986) ile farklılık göstermiş̧ir. Yem tüketiminin artması ya da azalması canlı ağırlık başta olmak üzere yemden yararlanma oranı, yumurta verimi ve diğer performans özelliklerinde değişime yol açmaktadır. Yem tüketiminde değişime neden olan faktörlerin başında ise selüloz gelmektedir. AK, selüloz içeriği yüksek olan (\%41) bir ürün olmakla birlikte bu çalışmada, yem tüketimi bakımından muameleler arasında farklılık ortaya çıkmamıştır $(\mathrm{P}>0,05)$. Tavukların yumurta verim düzeyine kalıtımın etkisi, 
$\% 15$ ile \% 25 arasında değişmekte (Şenköylü, 2001; Türkoğlu ve Sarıca, 2009) geri kalan etki ise çevreden, özellikle bakım ve beslemeden kaynaklanmaktadır.

Çizelge 3. Deneme tavuklarının canlı ağırlık değişim değerleri $(n=12)$

\begin{tabular}{ccccc}
\hline & $\begin{array}{c}\text { 1.gün } \\
\left(\mathrm{g} \mathrm{tavuk}^{-1}\right)\end{array}$ & $\begin{array}{c}\text { 21. gün } \\
\left(\mathrm{g} \mathrm{tavuk}^{-1}\right)\end{array}$ & $\begin{array}{c}\text { 42. gün } \\
\left(\mathrm{g}_{\text {tavuk }}{ }^{-1}\right)\end{array}$ & $\begin{array}{c}\text { 63. gün } \\
\left(\mathrm{g} \mathrm{tavuk}^{-1}\right)\end{array}$ \\
\cline { 2 - 5 } Gruplar & $\mathrm{X} \pm \mathrm{S}_{\mathrm{X}}$ & $\mathrm{X} \pm \mathrm{S}_{\mathrm{X}}$ & $\mathrm{X} \pm \mathrm{S}_{\mathrm{X}}$ & $\mathrm{X} \pm \mathrm{S}_{\mathrm{X}}$ \\
\hline 0-AK & $1739.5 \pm 53.57$ & $1830.8 \pm 43.95$ & $1881.8 \pm 45.38$ & $1980.5 \pm 33.64$ \\
3-AK & $1736.5 \pm 62.08$ & $1847.8 \pm 35.91$ & $1902.8 \pm 30.08$ & $2001.6 \pm 40.21$ \\
6-AK & $1741.0 \pm 59.48$ & $1854.9 \pm 54.44$ & $1948.8 \pm 48.86$ & $2010.6 \pm 44.74$ \\
9-AK & $1733.3 \pm 63.79$ & $1823.1 \pm 47.65$ & $1834.7 \pm 72.00$ & $1791.2 \pm 83.35$ \\
12-AK & $1745.2 \pm 64.69$ & $1821.5 \pm 50.43$ & $1948.3 \pm 50.38$ & $2029.7 \pm 59.79$ \\
15-AK & $1743.3 \pm 68.09$ & $1767.2 \pm 80.77$ & $1789.5 \pm 90.79$ & $1877.6 \pm 94.63$ \\
\hline P değeri & 1.00 & 0.89 & 0.35 & 0.06 \\
\hline
\end{tabular}

AK: Aspir küspesi, X: Ortalama, $\mathrm{S}_{\mathrm{X}}$ : Ortalamaların standart sapması

$\mathrm{Bu}$ çalışmada, yumurta verimine muamelelerin etkisi önemsiz bulunmuştur ( $\mathrm{P}>0.05$;Çizelge 4$)$. Bu bulgu, $\mathrm{AK}$ içeren rasyonların tavukların yumurta verimine etkisinin önemsiz olduğunu bildiren çalışmalarla (Ehsani ve ark., 2013; Barbour ve ark., 2016) uyum göstermektedir. Çalı̧̧maya ait gruplarda ölüm meydana gelmemiş, tavukların yaşama gücü muamelelerden etkilenmemiştir.

Rasyon enerjisinin artışı, her kilogram yumurta için tüketilen yem miktarında azalmaya yol açmak suretiyle yemden yararlanma oranında değişime neden olur (Grobas ve ark., 1999). Bu çalışmada, yem tüketim miktarları ve yumurta ağırlıklarına bağlı olarak yemden yararlanma oranı bakımından muamele grupları arasındaki farklılık önemsiz bulunmuştur $(\mathrm{P}>0.05)$. $\mathrm{Bu}$ sonuç, farklı düzeyde $\mathrm{AK}$ içeren rasyonların yumurtacı tavukların yemden yararlanma oranlarına etkilerinin önemsiz olduğu çalışma bulguları (Barbour ve ark., 2016) ile uyum göstermiştir. Bununla birlikte AK içeren rasyonların yumurta tavuklarını yemden yararlanma oranına etkisinin çok önemli olduğu araştırma bulguları (Ehsani ve ark., 2013) ile uyum göstermemiştir (Çizelge $4)$.

Çizelge 4. AK içeren rasyonların tavuklarının performans özelliklerine etkisi $(\mathrm{n}=12)$

\begin{tabular}{ccccc}
\hline & $\begin{array}{c}\text { Yem tüketimi, } \\
\mathrm{g}\end{array}$ & $\begin{array}{c}\text { Yumurta ağırlığı, } \\
\mathrm{g}\end{array}$ & $\begin{array}{c}\text { Yemden yararlanma } \\
\text { oranı, } \\
\text { g yem/g yumurta }\end{array}$ & $\begin{array}{c}\text { Yumurta verimi, } \\
\% \text { / tavuk / gün }\end{array}$ \\
\cline { 2 - 5 } Gruplar & $\mathrm{X} \pm \mathrm{S}_{\mathrm{X}}$ & $\mathrm{X} \pm \mathrm{S}_{\mathrm{X}}$ & $\mathrm{X} \pm \mathrm{S}_{\mathrm{X}}$ & $\mathrm{X} \pm \mathrm{S}_{\mathrm{X}}$ \\
\hline 0-AK & $121.9 \pm 2.30$ & $68.1 \pm 2.11$ & $1.79 \pm 0.05$ & $94.4 \pm 2.73$ \\
3-AK & $124.0 \pm 5.03$ & $68.8 \pm 1.69$ & $1.80 \pm 0.04$ & $98.9 \pm 0.32$ \\
6-AK & $127.4 \pm 2.24$ & $70.0 \pm 1.52$ & $1.82 \pm 0.04$ & $94.4 \pm 2.04$ \\
9-AK & $118.6 \pm 5.04$ & $67.9 \pm 1.56$ & $1.75 \pm 0.06$ & $90.1 \pm 2.32$ \\
12-AK & $132.0 \pm 2.13$ & $69.4 \pm 1.69$ & $1.90 \pm 0.04$ & $97.4 \pm 1.40$ \\
15-AK & $123.8 \pm 5.25$ & $69.4 \pm 2.03$ & $1.78 \pm 0.06$ & $91.6 \pm 3.50$ \\
\hline P değeri & 0.24 & 0.65 & 0.45 & 0.07 \\
\hline
\end{tabular}

AK: Aspir küspesi, $\mathrm{P} \leq 0.01, \mathrm{P} \leq 0.05$; aynı sütunda farklı harfler ile gösterilen ortalamalar arasındaki farklar önemlidir

\subsection{Yumurta kalitesi}

Yumurta ağırlı̆̆ındaki değişim üzerine muamelelerin etkisi önemsiz bulunmuştur $(\mathrm{P}>0.05$; Çizelge 4). Bu sonuç, Ehsani ve ark. (2013) farklı düzeylerde AK'nın tavukların yumurta ağırlıkları üzerine etkisinin önemli olmadığını bildirdikleri çalışma sonuçları ile benzerlik göstermiştir. Yumurta ağırlığına kalıtımın etkisi \% 55 olup (Şenköylü, 2001), rasyonların enerji (Harms ve ark., 2000; Bryant ve ark., 2005) yağ (Grobas ve ark., 1999; Sohail ve ark., 2003), protein (Liu ve ark., 2005; Wu ve ark., 2005), metiyonin (Schutte ve De Jong, 1994; Keshavarz, 1995; Bryant ve ark., 2005), lisin (Novak ve ark., 2004; Liu ve ark., 2005) ve linoleik asit (Whitehead, 1981) içeriklerine göre değişim gösterebilmektedir. Grupların yumurta 
kabuk ağırlığı, kabuk kalınlığı, kabuk kırılma direnci ve şekil indeksine muamelelerin etkisi önemli bulunmamıştır $(\mathrm{P}>0.05)$. Standart bir yumurtanın ortalama kabuk ağırlığı 6.4 gram (Türkoğlu ve Sarıca, 2009) olmasına karşın bu araştırmadan elde edilen yumurta kabuk ağırlıkları, yumurta ağırlıkları ile de uyumlu olarak \% 1 ile \% 2 kadar daha fazla olmuştur. Yumurta kabuk kalınlığında kalıtımın etkisi 0.20 ile 0.40 kadar olup, beslemenin etkisi daha fazladır.
Yumurtanın önemli dış kalite kriterlerinden birisi sayılan kabuk kalınlığı bu çalışmada 0.37 ile $0.39 \mathrm{~mm}$ arasında, kabuk kırılma direnci ise 1.83 ile $2.19 \mathrm{~kg} \mathrm{~cm}^{-2}$ arasında değişim göstermiştir (Çizelge 5). Yumurta ak indeksi, sarı indeksi, Haugh birimi, yumurta sarısı renk değeri ve yumurta sarı ağırlığı bakımından gruplar arasındaki farklılık önemli olmamıştır $(\mathrm{P}>0.05)$. Şekil indeksi değeri \% 77 ile \% 78, ak indeksi değerleri ise \% 7.18 ile \% 9.45 arasında değişim göstermiştir.

Çizelge 5. AK içeren rasyonlarla beslemenin tavukların yumurta dış kalite özelliklerine etkisi $(n=12)$

\begin{tabular}{ccccc}
\hline Gruplar & $\begin{array}{c}\text { Yumurta kabuk } \\
\text { ağırlığı, }\end{array}$ & $\begin{array}{c}\text { Yumurta kabuk } \\
\text { kalınlığı, } \mathrm{mm}\end{array}$ & $\begin{array}{c}\text { Yumurta kabuk } \\
\text { kirılma direnci, } \\
\left(\mathrm{kg} \mathrm{cm}^{-2}\right)\end{array}$ & $\begin{array}{c}\text { Yumurta } \\
\text { şekil } \\
\text { indeksi,\% }\end{array}$ \\
\cline { 2 - 5 } 0-AK & $8.9 \pm 0.20$ & $\mathrm{X} \pm \mathrm{S}_{\mathrm{X}}$ & $\mathrm{X} \pm \mathrm{S}_{\mathrm{X}}$ & $\mathrm{X} \pm \mathrm{S}_{\mathrm{X}}$ \\
\hline 3-AK & $8.8 \pm 0.31$ & $68.1 \pm 2.11$ & $1.8 \pm 0.17$ & $77.7 \pm 0.65$ \\
6-AK & $8.7 \pm 0.18$ & $70.0 \pm 1.52$ & $2.0 \pm 0.10$ & $77.0 \pm 0.46$ \\
9-AK & $8.6 \pm 0.18$ & $67.9 \pm 1.56$ & $1.8 \pm 0.10$ & $77.6 \pm 0.82$ \\
12-AK & $9.2 \pm 0.36$ & $69.4 \pm 1.69$ & $2.1 \pm 0.19$ & $78.5 \pm 0.43$ \\
15-AK & $8.6 \pm 0.12$ & $69.4 \pm 2.03$ & $1.9 \pm 0.14$ & $78.0 \pm 0.66$ \\
\hline P değeri & 0.51 & 0.65 & $1.8 \pm 0.13$ & $77.7 \pm 0.90$ \\
\hline
\end{tabular}

AK: Aspir küspesi

Taze yumurtada sarı indeksi \% 36 ile 44 arasında değişmektedir (Mineki ve Kobayashi, 1998). Bu çalışmada elde edilen yumurta sarı indeks değerleri $\% 43$ ile 45 arasında gerçekleşmiştir. Haugh birimi değeri $72 \geq$ olan yumurtalar ekstra taze (A sinıfi), 51-71 arasında olanları ekstra taze dişı (A sınıfi), $\leq 50$ olanları ise B sınıfı şeklinde sınıflandırılmaktadır (Anonim, 2015). Bu sınıflandırmaya göre mevcut çalışmadaki kontrol, 4. ve 6.gruplardan elde edilen yumurtalar AA sınıfında, diğer grupların yumurtaları ise A sınıfinda yer almıştır. Çalışmada AK'nın farklı dozlarına bağlı olarak, yumurtanın tazelik derecesinin göstergesi olan Haugh değerinde bir değişim meydana gelmemiştir $(\mathrm{P}>0.05)$.

Tavukların dışardan yemlerle almak zorunda oldukları ve büyük ölçüde yumurta sarısında depoladıkları toplam karotenoidlerin \%90'dan daha fazlasını lutein ile zeaksantin oluşturur (Kotrbáček ve ark., 2013). Yumurta sarı renk değeri, rasyonun pigment içeriğine ve yem tüketimine göre değişim gösterir. $\mathrm{Bu}$ çalışmada, tüketilen tüm rasyonların pigment içerikleri benzer olduğundan (20 mg karofil kırmızı ve $5 \mathrm{mg}$ karofil sarı $/ \mathrm{kg}$ yem), yumurta sarıs renk derecesine muamelenin etkisi önemsiz bulunmuştur $(\mathrm{P}>0.05)$. Sofralık yumurtalarda, yumurta sarısı renk yelpaze değerinin 11-12 arasında olması arzu edilir (Şenköylü, 2001). Bu çalışmada elde edilen yumurta sarısı renk değerleri 10.92 ile 11.17 arasında değişim göstermiștir (Çizelge 6).

Çizelge 6. AK içeren rasyonların tavukların yumurta dış kalite değerlerine etkisi $(n=12)$

\begin{tabular}{cccccc}
\hline \multirow{2}{*}{ Gruplar } & Ak indeksi,\% & Sarı indeksi,\% & Haugh değeri & $\begin{array}{c}\text { Sarı renk } \\
\text { değeri }\end{array}$ & Sarı ağırlığ, g \\
\cline { 2 - 6 } & $\mathrm{X} \pm \mathrm{S}_{\mathrm{X}}$ & $\mathrm{X} \pm \mathrm{S}_{\mathrm{X}}$ & $\mathrm{X} \pm \mathrm{S}_{\mathrm{X}}$ & $\mathrm{X} \pm \mathrm{S}_{\mathrm{X}}$ & $\mathrm{X} \pm \mathrm{SX}$ \\
\hline 0-AK & $8.2 \pm 0.32$ & $44.7 \pm 0.43$ & $79.8 \pm 1.52$ & $10.9 \pm 0.15$ & $17.1 \pm 0.40$ \\
3-AK & $7.5 \pm 0.61$ & $44.6 \pm 0.31$ & $74.6 \pm 3.02$ & $11.0 \pm 0.08$ & $17.6 \pm 0.17$ \\
6-AK & $7.1 \pm 0.29$ & $43.7 \pm 1.06$ & $73.7 \pm 1.63$ & $11.0 \pm 0.15$ & $17.3 \pm 0.47$ \\
9-AK & $8.5 \pm 0.34$ & $45.0 \pm 0.38$ & $80.1 \pm 1.36$ & $11.1 \pm 0.11$ & $16.5 \pm 0.28$ \\
12-AK & $7.2 \pm 0.33$ & $43.9 \pm 0.53$ & $74.6 \pm 1.97$ & $11.1 \pm 0.11$ & $17.0 \pm 0.42$ \\
15-AK & $9.4 \pm 1.34$ & $43.4 \pm 0.64$ & $79.8 \pm 2.50$ & $11.0 \pm 0.15$ & $17.3 \pm 0.58$ \\
\hline P değeri & 0.12 & 0.39 & 0.06 & 0.76 & 0.06 \\
\hline AK: Aspr
\end{tabular}

AK: Aspir küspesi 


\subsection{Yumurta sarısı yağ ve kolesterolü}

Araştırmanın 21 ve 63. günlerinde muamelelerin yumurta sarısı ham yă̆ oranlarına etkisi önemsiz $(\mathrm{P}>0.05)$ olmuştur (Çizelge 7). Yumurta sarısı kolesterol içeriğine muamelenin etkisi, çalışmanın 21.gününde önemsiz ( $\mathrm{P}>0.05)$, 63. gününde ise önemli olmuştur $(\mathrm{P}<0.02)$. Kolesterol değeri kontrol grubu dışında kalan gruplar arasında farklı bulunmuştur $(\mathrm{P}<0.05)$. Aspir tohumundaki fenolik bileşikler kısmen aspir küspesinde de bulunmaktadır ve bunlar hipokolesterolemik etkiye sahiptirler (Eldin ve ark., 2000). Diğer yandan bitki sterolleri bağırsakta kolesterol emilimini engellemekte (Sim ve ark., 1980), diyetin yağ içeriği ve çeşidi yumurta kolesterol miktarını \% 16 ile \% 33 oranında azaltmaktadır (Sim ve Bragg, 1977).

İnsanlara nazaran tavuklar her kg karaciğer ağırlığ için 10 kat daha fazla kolesterol üretebilmektedir. $\mathrm{Bu}$ yüzden yumurta sarısı kolesterol miktarı diyet faktörlerinden bağımsız olarak sabit kalmakta ve diyet manipülasyonu ile kolesterol düzeyini azaltmak çok etkili olmamaktadır (Bertechini, 2003). Kanatl hayvanlarda embriyo gelişimini sağlayacak düzeyde kolesterole gerek duyulduğundan, kolesterol miktarındaki değişime karşı yumurta sarısı oldukça dirençlidir (Shafey ve Cham, 1994). Böyle olmakla beraber doymamış yağ asitlerince zengin diyetler kolesterol düzeyini (Ling ve Jones, 1995; Vanstone ve ark., 2001; Faitarone ve ark., 2013) ve kan kolesterol düzeyini azaltmaktadır (Holland ve ark., 1980; Mori, 2001). Standart bir tavuk yumurtasının kolesterol içeriği $220 \mathrm{mg}$ dolayında olup (Simopoulos, 2000) yapılan beslemeye bağlı olarak \% 5 ile \% 30 arasında bir değişim meydana gelebilmektedir (Şenköylü, 2001). Bu çalışmada elde edilen yumurtaların kolesterol miktarları standart değerin üzerinde $(276-320 \mathrm{mg})$ olmuştur (Çizelge 7). Bu çalışmada kontrol grubu ve diğer gruplar arasındaki yumurta kolesterol miktarındaki değişimin rasyon $\mathrm{AK}$ ve yağ içeriklerinden kaynaklandığı düşünülmektedir. Yumurta kolesterol düzeyi genotip, yaş ve bakım gibi bir çok faktörler tarafindan etkilenmekte ancak beslemenin etkisi daha sınırlı olmaktadır (Hargis, 1988; Hargis ve ark., 1991).

Çizelge 7. AK içeren rasyonlarla beslenen tavukların yumurta sarısı ham yağı ve kolesterol miktarları (n=3)

\begin{tabular}{ccccc}
\hline & \multicolumn{2}{c}{ Yumurta sarısı ham yağ1,\% } & \multicolumn{2}{c}{ Yumurta sarıs1 kolesterolu, mg } \\
\cline { 2 - 5 } Gruplar & 21. gün & 63. gün & 21. gün & 63.gün \\
\cline { 2 - 5 } & $\mathrm{X} \pm \mathrm{S}_{\mathrm{X}}$ & $\mathrm{X} \pm \mathrm{S}_{\mathrm{X}}$ & $\mathrm{X} \pm \mathrm{S}_{\mathrm{X}}$ & $\mathrm{X} \pm \mathrm{S}_{\mathrm{X}}$ \\
\hline 0-AK & $32.4 \pm 0.49$ & $31.7 \pm 0.21$ & $292.0 \pm 4.50$ & $294.6 \pm 12.54 \mathrm{abc}$ \\
3-AK & $31.2 \pm 0.83$ & $32.5 \pm 0.88$ & $298.3 \pm 8.61$ & $320.4 \pm 2.77 \mathrm{a}$ \\
6-AK & $31.4 \pm 0.86$ & $32.9 \pm 0.99$ & $308.4 \pm 4.16$ & $308.8 \pm 2.49 \mathrm{ab}$ \\
9-AK & $32.8 \pm 0.38$ & $32.2 \pm 0.92$ & $293.1 \pm 3.03$ & $291.7 \pm 3.86 \mathrm{bc}$ \\
12-AK & $32.5 \pm 0.92$ & $32.7 \pm 0.76$ & $303.1 \pm 6.62$ & $277.3 \pm 6.17 \mathrm{c}$ \\
15-AK & $31.8 \pm 0.79$ & $31.6 \pm 0.63$ & $284.4 \pm 8.92$ & $296.8 \pm 10.92 \mathrm{abc}$ \\
\hline P değeri & 0.16 & 0.16 & 0.14 & 0.02 \\
\hline
\end{tabular}

AK: Aspir küspesi, $\mathrm{P} \leq 0.01, \mathrm{P} \leq 0.05$; aynı sütunda farklı harfler ile gösterilen ortalamalar arasındaki farklar önemlidir.

\subsection{Yumurta sarlsı yă̆ asitleri}

Yumurtanın ana bileşeni olan lipitler, diyet manipülasyonu ile kolayca etkilenmekte (Naber, 1979), doymamış yağ asitleri bakımından zengin olan diyetler, yumurta sarısının lipit profilini değiş̧irmektedir (Shafey ve ark., 1999; Martino ve ark., 2002). Yemler ile alınan yağların portomikronlar şeklinde doğrudan kan içine absorbe edilmesi ve lipogenesisin ana merkezi karaciğere taşınmasından dolayı diyet lipit kaynağına bağlı olarak, tavukların yumurta sarısı yağ asitleri içeriğinin değiştirilebilmesi mümkün görülmektedir (Van-Elswky ve ark., 1994). Bu çalışmanın 21. ve 63. günlerinde muamelelerin yumurta sarısı toplam doymuş yağ asitlerine etkisi önemli $(\mathrm{P}<0.05)$ olmuştur (Çizelge 8). Kontrol grubuna nazaran diğer muamele gruplarının toplam doymuş yağ asitlerinde bir azalma meydana gelmiştir.
$\mathrm{Bu}$ araştırmada, yumurta sarısı toplam doymamış yăg asitleri üzerine muamelelerin etkisi 21. günde önemsiz, 63. günde elde edilen verilere göre ise önemli bulunmuştur $(\mathrm{P}<0.01)$. Kontrol grubuna nazaran, $\mathrm{AK}$ içeren grupların yumurta sarısı toplam doymuş yağ asitleri oranında azalma, toplam doymamış yağ asitleri oranında ise kısmi bir artış meydana gelmiştir (Çizelge 8). Grupların yumurta sarısı yağ asitlerindeki meydana gelen azalma ve artışların rasyonların soya yağı oranları ile ilgili olabileceği düşünülmektedir.

\section{Sonuç}

Performans ve yumurta kalite özelliklerini olumsuz etkilemeksizin, yumurtacı tavukların rasyonlarına \%15 düzeyine kadar $\mathrm{AK}$ kullanımının mümkün olduğu görülmüştür.

Bu çalışmada AK kullanımı, SK'dan \% 4.6'a kadar 
tasarruf sağlamıştır. Bu sonuç, AK'nın yumurtacı tavuk yemlerinde alternatif bir protein kaynağ kullanım potansiyeli hakkında bir fikir ortaya koymuştur. Rasyon hazırlamada, AK'nın yüksek selüloz ve düşük enerji içeriği dikkate alınmalıdır.
Rasyonlardaki soya yağı miktarıyla uyumlu olarak, yumurta sarısı doymamış yağ asitleri içeriğinde bir artış meydana gelmiştir.

Çizelge 8. AK içeren rasyonlarla beslenen tavukların yumurta sarısı yağ asitleri miktarı $(n=3)$

\begin{tabular}{ccccc}
\hline & \multicolumn{2}{c}{ Yumurta sarısı doymuş yağ asitleri, \% } & \multicolumn{2}{c}{ Yumurta sarıs1 doymamış yağ asitleri, \% } \\
\cline { 2 - 5 } Gruplar & 21. gün & 63.gün & 21.gün & 63.gün \\
\cline { 2 - 5 } 0-AK & $\mathrm{X} \pm \mathrm{S}_{\mathrm{X}}$ & $\mathrm{X} \pm \mathrm{S}_{\mathrm{X}}$ & $\mathrm{X} \pm \mathrm{S}_{\mathrm{X}}$ & $\mathrm{X} \pm \mathrm{S}_{\mathrm{X}}$ \\
\hline 3-AK & $32.2 \pm 0.54 \mathrm{a}$ & $31.6 \pm 0.44 \mathrm{ab}$ & $66.1 \pm 0.66$ & $66.5 \pm 0.70 \mathrm{~b}$ \\
6-AK & $32.5 \pm 0.62 \mathrm{a}$ & $31.9 \pm 0.22 \mathrm{a}$ & $65.4 \pm 0.76$ & $66.4 \pm 0.10 \mathrm{~b}$ \\
9-AK & $32.5 \pm 0.24 \mathrm{a}$ & $31.4 \pm 0.27 \mathrm{ab}$ & $65.4 \pm 0.57$ & $67.2 \pm 0.46 \mathrm{ab}$ \\
12-AK & $32.1 \pm 0.13 \mathrm{ab}$ & $30.7 \pm 0.15 \mathrm{bc}$ & $66.2 \pm 0.08$ & $67.7 \pm 0.20 \mathrm{ab}$ \\
15-AK & $31.3 \pm 0.25 \mathrm{ab}$ & $30.3 \pm 0.16 \mathrm{~cd}$ & $66.8 \pm 0.23$ & $68.4 \pm 0.41 \mathrm{a}$ \\
\hline P değeri & $30.8 \pm 0.30 \mathrm{~b}$ & $29.9 \pm 0.21 \mathrm{~d}$ & $67.3 \pm 0.26$ & $68.2 \pm 0.20 \mathrm{a}$ \\
\hline
\end{tabular}

AK: Aspir küspesi, $\mathrm{P} \leq 0.01, \mathrm{P} \leq 0.05$; aynı sütunda farklı harfler ile gösterilen ortalamalar arasındaki farklar önemlidir

\section{Teşekkür}

$\mathrm{Bu}$ projeye (2013/3-24 YLS) gerekli mali desteği sağlayan Kahramanmaraş Sütçü İmam Üniversitesi’ne (KSÜ BAP) teşekkür ederiz.

\section{Kaynaklar}

Abughazaleh, A.A., Riley, M.B., Thies, E.E., Jenkins, T.C. 2005. Dilution rate and $\mathrm{pH}$ effects on the conversion of oleic acid to trans $\mathrm{C} 18: 1$ positional isomers in continuous culture. J. Dair.Sci., 88: 4334-4341.

Alvarez-Gonzalez, C.A., Lopez-Gonzalez, B., GutierrezLeyva, R., Goytortua-Bores, E., Civera-Cerecedo, R. 2007. Use of safflower Carthamus tinctorius products in diets for tilapia Oreochromis niloticus. Effects on growth and apparent digestibility. Caribbean \& Latin American Aquaculture, 6-9 November. San Juan, Puerto Rico.

Anonim, 2015. Kabuklu tavuk yumurtası standard1. TS 1068, Türk Standartları Enstitüsü.

AOAC, 2005. Official Methods of Analysis, 18th Edn. Washington D.C. Method numbers: 960.52, 923.09 ve 920.39.

Barbour, G.W., Usayran, N.N., Yau, S.K., Murr, S.K., Shaib, H.A., Abi Nader, N.N., Salameh, G.M., Farran, M.T. 2016. The effect of safflower meal substitution in a lysine fortified corn-soybean meal diet on performance, egg quality, and yolk fat profile of laying hens. J.App. Poult. Res., 25(2):256-265.

Baümler, E., Cuniberti, A., Nolascoa, S.M., Riccobene, I.C. 2006. Moisture dependent physical and compression properties of safflower seed. J. Food Eng., 72 (2): 134140. blood parameters of broiler chicks. Indian Vet. J., 84: 610-612.
Batal, A., Dale N., Farms, S. 2016. Feedstuffs, Ingredient Analysis Table: 2016 edition. Athens, GA. Nutrient content of safflower seed meal.

Bertechini, A.G. 2003. Mitos e verdades sobre o ovo de consumo. 21 th Conferência de Ciência e Tecnologia Avícola; Santos, São Paulo. Brasil., s:19.

Boehringer Mannheim Biochemica, 1989. Methods of Biochemical Analysis and Food Analysis., s: 26-28. Mannheim, Germany.

Bryant, M., Wu, G., Rolve, D.R. 2005. Optimizing dietary energy for profits and performance of two strains of White Leghorns. Proceedings of the International Poultry Scientific Forum Abstracts; Atlanta, GA., s:23.

Carpenter, K.J., Clegg, K.M., 1956. The metabolizable energy of poultry feeding stuffs in relation ro their chemical composition. J. Sci. Food. Agric., 7: 45-51.

Dajue, L., Mündel, H.H. 1996. Safflower (Carthamus tinctorius L.). Promoting the conservation and use of underutilized and Neglected Crops 7. Institute of Plant Genetics and Crop Plant Research. International Plant Genetic Resources Institute, pp:83, Gatersleben/TPGRI, Rome, Italy. ISBN 92-9043-297-7

Darroch, C.S., 1990. Safflower meal. In: Thacker, PA., and Kirkwood, RN.,(eds). Nontraditional feed sources for use in swine production, Butterworths, Stoneham, Massachusetts., s: 373-382.

Dubois, M., Gilles, K.A., Hamilton, J.K., Rebers, P.A., Smith, F. 1956. Colorimetric method for determination of sugars and related substances. Anal. Chem. 28:350-356.

Ehsani, A., Mahdavi, A.H., Samie, A.H., Dolatkhah, B. 2013. Effects of dietary administration of multi-enzyme on productive performance of laying hens fed different levels of safflower meal. J. of Anim. and Poult. Sci., 2(4): 108-119

Eldin, A.K., Franka, J., Razdan, A., Tengblad, S., Basu, S., Vessby, B. 2000. Effects of dietary phenolic compounds on tocopherol, cholesterol, and fatty acids in rats. Lipids, Vol. 35, no. 4. 
Faitarone, A.B.G., Garcia, E.A., Roça R de O., Ricardo, H de A., Verade, EN de V., Pelícia K., Vercese F. 2013. Cholesterol levels and nutritional composition of commercial layers eggs fed diets with different vegetable oils. Revista Brasileira de Ciência Avícola; vol. 15 no. 1 .

Farran, M.T., Barbour, G.W., Usayran, N.N., Kayouli, C. 2010. Metabolizable energy and aminoacid digestibility of decorticated extruded safflower meal. Poult. Sci.;89 (9):1962-1966.

Folch, J., Lees, M., Stanley, G.H.S. 1957. A simple method for the isolation and purification of total lipids from animal tissues. J. Bio. Chem., 226: 497-509.

Gowda, N.K.S., Ramana, J.V., Prasad, C.S., Singh, K. 2004. Micronutrient content of certain tropical conventional and unconventional feed resources of Southern India. Trop. Anim. Health Prod., 36 (1): 77-94.

Göhl, B., 1982. Les aliments du bétail sous les tropiques. FAO, Division de Production et Santé Animale, Roma, Italy.

GRDC, 2010. Raising the bar with better safflower agronomy - Autumn 2010. GRDC - Grain research and development corporation.

Grobas, S., Mendez, J., De Blas, C., Mateos, G.G.. 1999. Laying hen productivity as affected by energy, supplemental fat, and linoleic acid concentration of the diet. Poult. Sci. 78:1542-1551.

Hargis, P.S. 1988. Modifying egg yolk cholesterol in the domestic fowl-a review. World's Poult. Sci. J. 44: 1729.

Hargis, P.S, Van Elswyk, M.E., Hargis, B.M. 1991. Dietary modification of yolk lipid with savelha oil. Poult. Sci.;70:874-883.

Harms, R.H., Russell, G.B., Sloan, D.R. 2000. Performance of four strains of commercial layers with major changes in dietary energy. J. Appl. Poult. Res. 9:535-541.

Hertrampf, J.W., Piedad-Pascual, F. 2000. Handbook on ingredients for aquaculture feeds. Kluwer Academic Publishers., s:624.

Heuzé, V., Tran, G., Chapoutot, P., Renaudeau, D., Bastianelli, D., Lebas, F., 2015. Safflower (Carthamus tinctorius) seeds and oil meal. Feedipedia, a programme by INRA, CIRAD, AFZ ve FAO. http://feedipedia.org/node/49 Last updated on October 6, $10: 51$.

Holland, K.G., Grunder, A.A., Williams, C.L. 1980. Response to five generations of selection for blood cholesterol levels in White Leghorns. Poult. Sci.;59:1316-26.

Karabulut, A., Canbolat, Ö. 2005. Yem değerlendirme ve analiz yöntemleri. Uludağ Üniversitesi Yayınları. Yayın No: 2.05.048.0424, Bursa.

Keshavarz, K., 1995. Further investigations on the effect of dietary manipulations of nutrients on early egg weight. Poult. Sci., 74: 62-74.

Kotrbáček, V., Skřivan, M., Kopecký J., Pěnkava, O., Hudečková P., Uhríková, I., Doubek, J., 2013. Retention of carotenoids in egg yolks of laying hens supplemented with heterotrophic chlorella. Czech J. of Anim. Sci., 58(5): 193-200.

Ling, W.H., Jones, P.J.H. 1995. Enhanced efficacy of sitostanolcontaining versus sitostanol-free phytosterol mixtures in altering lipoprotein cholesterol levels and synthesis in rats. Atherosclerosis. 118: 319-331.

Liu, Z., Wu, G., Bryant, M.M., Rolve, D.A. 2005. Influence of added synthetic lysine in low-protein diets with the methionine plus cysteine to lysine ratio maintained at 0.75. J. Appl. Poult. Res., 14: 174-182.

Martino, R.C., Cyrino, J.E.P., Portz, L., Trugo, L.C. 2002. Performance and fatty acid composition of surubim (Pseudoplatystoma coruscans) fed diets with animal ve plant lipids. Aquaculture, 209: 233-246.

Mineki, M., Kobayashi, M. 1998. Microstructural changes in stored hen egg yolk. J.Poultr. Sci. 35: 285-294.

Mohan, L., Reddy, C.V., Rao, P.V., Siddiqui, S.M. 1984. Safflower meal as a protein sourcein broiler rations. Indian J. Anim. Sci.54:870-875.

Mori, A.V. 2001. Utilização de óleo de peixe e linhaça na ração como fontes de ácidos graxos poliinsaturados ômega 3 em ovos [tese]. São Paulo (SP): Universidade de São Paulo, Brasília.

Mündel, H.H., Blackshaw, R.E., Byers, J.R., Huang, H.C., Johnson, D.L., Keon, R., Mündel H.H., Morrison R.J., Blackshaw, R.E., Roth, B. 2004. Safflower production on the Canadian prairies. Agricultural Research Stations. Lethbridge, Canada, pp:43. ISBN: 0-662-38209-9.

Naber, E.C. 1979. The effect of nutrition on the composition of eggs. Poultry Science;58: 518-28.

Nagaraj, G. 1993. Safflower seed composition ve oil quality a review. Proceedings of the 3rd International Safflower Conference, June 14-18, Beijing, China, pp: 58-71.

Novak, C., Yakout, H., Scheideler, S. 2004. The combined effects of dietary lysine and total sulfur amino acid level on egg production parameters and egg components in dekalb delta laying hens. Poult. Sci. 83: 977-984.

NRC (National Research Council), 1994. Nutrient Requirements of Poultry. edn. 9th, The National Academy of Sciences., National Academy Press, Washington, D.C.

Oyen, L.P.A., Umali, B.E. 2007. Carthamus tinctorius L.. Record from Protabase. van der Vossen, H.A.M., Mkamilo, G.S. (Editors). PROTA (Plant Resources of Tropical Africa / Ressources végétales de l'Afrique tropicale), Wageningen, Netherlands.

Palter, R., Lundin, R.E., Haddon, W.F. 1972. A cathartic lignan glycoside isolated from Carthamus tinctorus. Phytochemistry 11: 2871-2874.

Petersen, C.F., Meyer, G.B., Sauter, E.A. 1976. Comparison of metabolizable energy values of feed ingredients for chicks and hens. Poult. Sci., 55 (3): 1163-1165.

Rahamatalla, A.B., Babiker, E.E., Krishna, A.G., El Tinay, A.H. 2001. Changes in fatty acids composition during seed growth and physicochemical characteristics of oil extracted from four safflower cultivars. Plant Food for Hum. Nutr..56: 385-395.

Rehman, A., Malik, M.Y. 1986. Safflower meal as a protein source in broiler rations. Pak.J. Bioc. 19:39-42.

Sakamura, S., Terayama .Y, Kawakatsu S., Ichihara A., Saito, H. 1978. Conjugated serotonins related to cathartic activity in safflower seeds (Carthamus tinctorious L.). Agric Biol. Chem 42: 1805-1806.

SAS, 2005. Statistical analysis system, Institute Inc. User Guide. Carry, North Carolina U.S.A.

Schutte, J.B., De Jong, J. 1994. Requirement of the laying hen for sulfur amino acids. Poult. Sci., 73:274-280.

Shafey, T.M., Cham, B.E. 1994. Altering fatty acid and cholesterol contentes of eggs for human comsuption. In: Sim JS, Nakai S. Egg uses and processing technologies: new developmentes. Washington: CAB International; $\mathrm{p}$. 374-85

Shafey, T.M., Dingle, J.G., Mcdonald, M.W. 1999. Comporison between wheat, triticale, rye, soybeanoil 
and strain of laying bird on the production and cholesterol and fatty acid content of eggs. Brith. Poult. Sci., 33: 339-346.

Sim, J.S., Bragg, D.B. 1977. Effect of dietary factors on serum and egg yolk cholesterol levels of laying hens. Poult. Sci., 56: 1616-1621.

Sim, J.S., Kitts, W.D., Bragg, D.B. 1980. Influence of dietary oil, cholesterol and soysterols on the fecal neutral and acidic steroid excretion in laying hens. Poult. Sci. 59:325-327.

Simopoulos, A.P. 2000. Human requirement for $n-3$ polyunsaturated fatty acids. Symposium: Role of poultry products in enriching the human diet with n-3 PUFA. Poult. Sci.79:961-970.

Sohail, S.S., Bryant, M.M., Roland, D.A. 2003. Influence of dietary fat on economic returns of commercial Leghorns. J. Appl. Poult. Res., 12:356-361.

Şenköylü, N., 2001. Modern Tavuk Üretimi. Gözden geçirilmiş ve genişletilmiş 3. baskı. Trakya Üniversitesi,
Tekirdağ Ziraat Fakültesi, Hayvansal Üretim Bölümü, Anadolu Matbas1., s: 82.

Türkoğlu, M., Sarıca, M. 2009. Tavukçuluk bilimi (yetiştirme, besleme, hastalıklar). Bey Ofset Matbaacilık., s; 327.

Van-Elswky, M.E., Hargis, B.M., Willians, J.D., Hargis, P.S. 1994. Dietary menhaden oil contributes to hepatic lipidosis in laying hens. Poult. Sci.;73(5):653-62.

Vanstone, C.A., Raeini-Sarjaz M., Jones, J.H.P. 2001. Injected phytosterol/stanol suppress plasma cholesterol levels in hamsters. The J. of Nutr. Bioc. 12:565-574.

Weiss, E.A. 2000. Safflower. In: Oilseed crops, Blackwell Sci. Ltd., Victoria, Australia., s:93-129.

Whitehead, C.C. 1981. The response of egg weight to the inclusion of vegetable oil and linoleic acid in the diet of laying hens. Br. Poult. Sci., 22: 525-532.

Wu, G., Bryant, M.M., Rolve, D.A. 2005. Effect of synthetic lysine on performance of commercial leghorns in phase II ve III (second cycle) while maintaining the methionine+cysteine/lysine ratio at 0.75 . International Poultry Scientific Forum Abstracts, Atlanta, USA., s:43. 